\title{
Banana Production Trends, Cultivar Diversity, and Tissue Culture Technologies Uptake in Kenya
}

\author{
Caroline N. Wahome, ${ }^{1}$ John M. Maingi $\left(D,{ }^{1}\right.$ Omwoyo Ombori, ${ }^{1}$ \\ Jacinta M. Kimiti, ${ }^{2}$ and Ezekiel M. Njeru ${ }^{1}$ \\ ${ }^{1}$ Department of Biochemistry Microbiology and Biotechnology, Kenyatta University, Nairobi, Kenya \\ ${ }^{2}$ Department of Environmental Science and Land Resources Management, South Eastern Kenya University, Kitui, Kenya \\ Correspondence should be addressed to John M. Maingi; maingijohn@gmail.com
}

Received 28 October 2020; Revised 19 January 2021; Accepted 30 January 2021; Published 16 February 2021

Academic Editor: Maria Serrano

Copyright (C) 2021 Caroline N. Wahome et al. This is an open access article distributed under the Creative Commons Attribution License, which permits unrestricted use, distribution, and reproduction in any medium, provided the original work is properly cited.

\begin{abstract}
Banana (Musa acuminate L) is the world's most widely known and distributed fruit and is a great contributor to food security in the developing world. However, many limiting factors affect banana farming, which cut across sociodemographic factors and agronomic and management practices. The current study was carried in three counties, including Kisii, Nyamira, and Embu. The study aimed to assess agronomic practices, banana production practices (main banana cultivars, source of planting materials), market information, and awareness of tissue culture bananas. Sample size was determined using the Snedecor and Cochran formula, and data were collected using structured questionnaires, observation, and face to face interviews from 90 smallholder farmers. Data obtained were analysed using Statistical Package for Social Sciences (SPSS) version 22.0, and Microsoft Excel was used to generate tables and graphs. Results indicated that banana production in Kisii, Nyamira, and Embu were limited by several factors including pests and diseases, limited access to quality disease-free planting materials, access to extension services, especially in Kisii and Nyamira, as well as access to agrochemicals. Declining production as well as limited market access also adversely affected production in these regions. Most farmers chose cultivars according to the availability of planting materials, suitability to the region, productivity, as well as market demand. The most predominant cultivar in Kisii and Nyamira was the Ng'ombe which was planted by about $90 \%$ and $73.3 \%$ of the respondents, respectively. In Embu, the most common cultivar was Israel and was planted by $96 \%$ of the respondents. More than $50 \%$ of the farmers in Kisii, Nyamira, and Embu cited lack of awareness of tissuecultured bananas. None of the respondents in the study sites carried out any value addition processes on bananas thus limiting exploitation of a major revenue source. There was low adoption of tissue-cultured banana cultivation with the highest recorded number of respondents growing tissue-cultured banana reported in Embu (36\%), followed by Kisii (10\%) and lastly Nyamira (3.3\%), as well as limited knowledge of tissue culture technology in three counties with $60 \%$ of the respondents in Kisii, Nyamira, and Embu indicating limited knowledge of the tissue-cultured banana varieties. This could potentially lead to a decline in production due to the use of potentially diseased planting materials. Creating awareness with the aid of relevant authorities on the potential benefits of utilizing disease-free tissue-cultured bananas and adopting low-cost tissue culture technology will significantly boost banana production in these regions and the country as a whole. The results of this study could be used by relevant stakeholders to increase banana productivity in the study areas.
\end{abstract}

\section{Introduction}

Banana is one of the staple food crops for both rural and urban populations in Kenya, and it is predominantly grown by smallholder farmers. It is grown for both home consumption and the national market, and it has the potential to contribute to food and nutritional security, as well as a source of income for smallholder farmers [1]. Most banana farmers grow dual-purpose cultivars that can serve as cooking and dessert varieties. Characteristics such as local tastes, eating habits, market demand, and environmental conditions tend to influence banana distribution [2]. 
Cooking varieties commonly grown include Uganda green, Ng'ombe, Nusu Ng'ombe, Mutahato, and Gradi shiskame, while dessert varieties include apple banana (Ndizi sukari), Bokoboko, giant Cavendish, Chinese Cavendish, Gros Michel, Kampala, Bogoya, and Muraru [3, 4].

Conventional and modern methods of propagation are used in the production of bananas in Kenya [5]. The conventional method of propagation of bananas using suckers is a very slow process resulting in low production because a banana plant produces only 5-20 suckers in its lifetime [6]. In addition, the spread of pests and diseases through banana suckers as planting materials is a major drawback in the conventional method of propagation [1]. Consequently, there is a limited supply of clean planting materials since $60 \%$ of banana growers in East and Central Africa obtain suckers from their own existing fields [7].

The ability of smallholder farmers to sell produce profitably in the staple food market has declined over the years due to the changes in both the formal and informal channels of traders, processors, and markets. The development of collective marketing strategies are necessary to help the farmer overcome high transaction costs and low market power that leave them at the mercy of middlemen [8]. It has been suggested that collective actions through smallholder farmer pooling of resources will ease marketing constraints and adoption of technologies [9].

Tissue culture (TC) offers the opportunity of producing large numbers of disease-free seedlings. The use of tissue culture technology in banana production is highly efficient, as it allows a timely large turnover of clean planting materials within a limited space $[10,11]$. Therefore, tissue culture technology has the potential to contribute significantly to yield. However, farmers are yet to adopt TC technology $[1,5]$. While the literature on the adoption and impact of crop technologies is large, there is limited information on specific cultivars grown as well as the rate of adoption and the effect of adoption in small-scale farming sector. Identifying commonly planted banana cultivars in Kisii, Nyamira, and Embu counties and the factors influencing the choice of cultivar as well as the level of adoption of technologies is an important step in improving banana production in these regions. This study aimed at assessing banana cultivars grown in Kisii, Nyamira, and Embu counties, their farming practices and the awareness, and level of adoption of tissue-cultured bananas by smallholder farmers in the three counties. These counties were chosen based on the fact that they are among the leading banana producers in Kenya among others such as Meru, Kirinyaga, and Muranga [12].

\section{Materials and Methods}

2.1. Study Site Description. The study was carried out in Kisii, Nyamira, and Embu counties (Figure 1) which are among the leading banana producing counties in Kenya. Kisii County covers an area of $1,317 \mathrm{~km}^{2}$ and exhibits a typical highland equatorial climate with a bimodal rainfall pattern averaging between 1500 and $2100 \mathrm{~mm}$ annually and temperatures ranging between $19^{\circ} \mathrm{C}$ and $30^{\circ} \mathrm{C}$ [13]. Nyamira County lies between latitudes $0^{\circ} 30^{\prime}$ and $0^{\circ} 45^{\prime}$ South and $34^{\circ} 45^{\prime}$ and $35^{\circ} 00^{\prime}$ East and receives an average annual rainfall and temperatures between 1700 and $2000 \mathrm{~mm}$ and $15^{\circ} \mathrm{C}$ and $27^{\circ} \mathrm{C}$, respectively [14]. Embu County is located on the southeastern part of Mt. Kenya, and it lies at $0.53^{\circ} \mathrm{S}, 37.45^{\circ} \mathrm{E}$ and has an average temperature that ranges between $12^{\circ} \mathrm{C}$ and $30^{\circ} \mathrm{C}$ with an elevation ranging from $1000 \mathrm{~m}$ to $1600 \mathrm{~m}$ above the sea level [15].

2.2. Data Collection. A household survey was conducted based on purposive sampling in households with 30 and above banana stalks. Data were collected using a structured questionnaire which was administered through face to face interviews with smallholder farmers in Kisii, Nyamira, and Embu counties. A total of 90 farm households were identified, and primary data were collected. Thirty smallholder farms were from Kisii (Suneka), 30 from Nyamira County (Kemera), and 30 from Embu County (Kiangungi and Muganjuki). The questionnaires covered demographic information, information on banana production practices such as main cultivars grown, source of planting materials, as well as awareness of tissue culture technology and adoption. Purposive sampling conducted in which households had thirty and above banana stems in their farms were randomly sampled. Data obtained were analysed using Statistical Package for Social Sciences (SPSS) version 22.0 computer software in which descriptive analyses were carried out. Microsoft Excel program was used to generate graphs. The sampling size of households was obtained using the Snedecor and Cochran formula [16].

$$
n=\frac{4 p q}{(L)^{2}}
$$

where $p=$ proportion in the target population, $q=1-p$, $n=$ sample size, and $L=$ accepted error. The population in this study refers to the number of households.

Embu County' household target population was 14,300, and the proportion of 363 smallholder farmers was used to determine the sample size.

$$
\begin{aligned}
p & =\frac{363}{14,300}=0.025, \\
q & =1-0.025=0.975, \\
L^{2} & =(0.05)^{2}=0.0025, \\
n & =\frac{(4 \times 0.025 \times 0.975)}{0.0025}=39 .
\end{aligned}
$$




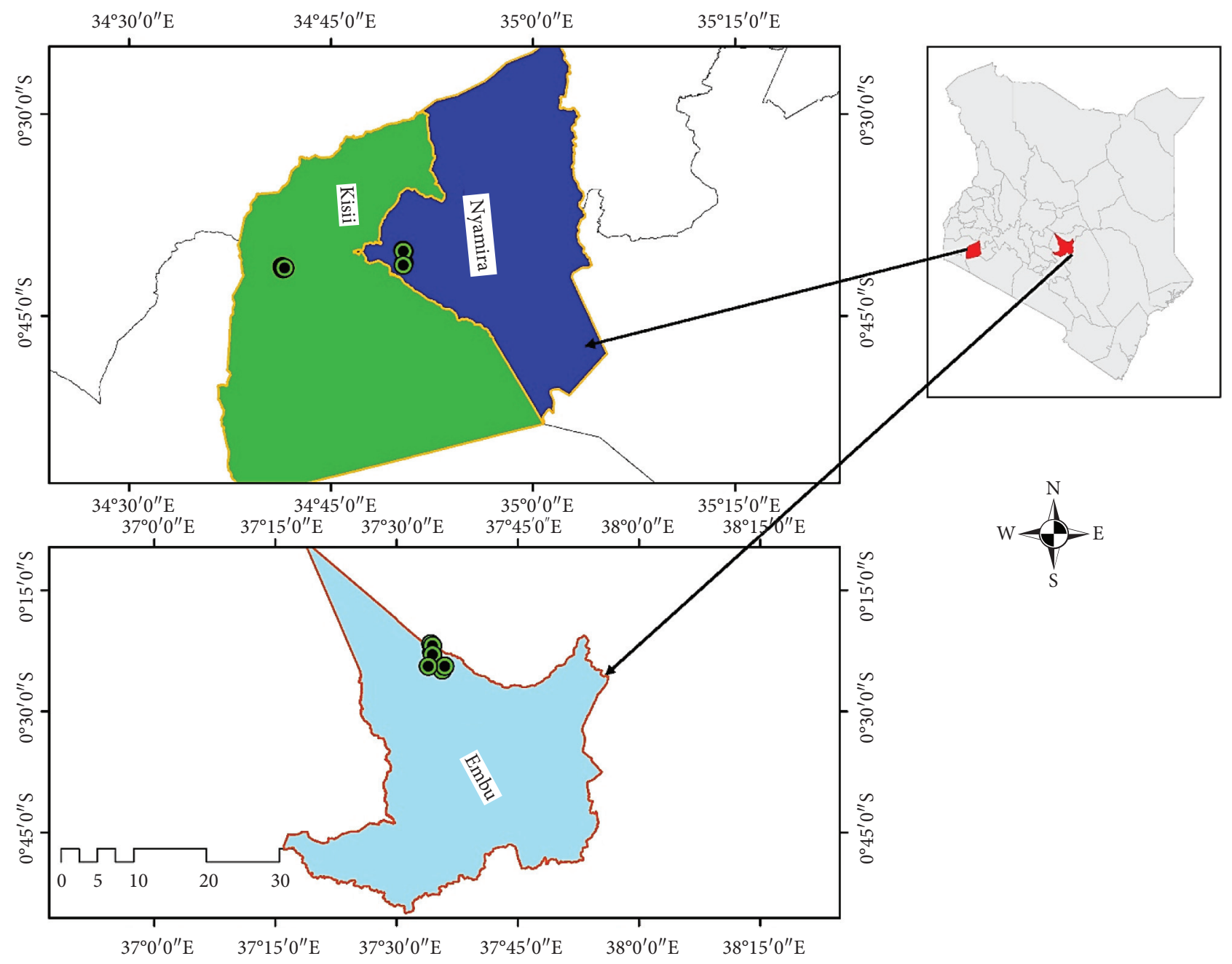

Data collection ponts

Counties of interest

$\begin{array}{ll}\square \text { Embu } & \text { Nyamira } \\ \text { Kisii } & \text { Other counties }\end{array}$

Coordinate system: GCS WGS 1984

Datum: WGS 1984

Units: degree

Figure 1: Map of study regions in Kisii, Nyamira, and Embu counties generated from GPS coordinates.

Kisii County' target household population was 13,405, and the proportion of 255 smallholder farmers was used to determine the sample size.

$$
\begin{aligned}
P & =\frac{255}{13,405}=0.019, \\
q & =1-0.019=0.981, \\
L^{2} & =(0.05)^{2}=0.0025, \\
n & =\frac{(4 \times 0.019 \times 0.981)}{0.0025}=29.8 .
\end{aligned}
$$

Nyamira County' target household population was 15,307 , and the proportion of 279 smallholder farmers was used to determine the sample size.

$$
\begin{aligned}
P & =\frac{279}{15,307}=0.018, \\
q & =1-0.018=0.982, \\
L^{2} & =(0.05)^{2}=0.0025, \\
n & =\frac{(4 \times 0.018 \times 0.982)}{0.0025}=28.2 .
\end{aligned}
$$




\section{Results and Discussion}

\subsection{Sociodemographic Factors}

3.1.1. Gender and Age. It was observed that majority of the respondents in the three counties were male with Embu, Kisii, and Nyamira counties recording 53.3\%, 60\%, and $63.3 \%$, respectively (Table 1 ). Gender is a very important variable especially when studying household agricultural practices and adoption of technology. It has been observed that the current societal values and practices show predominantly male-headed households. Males are advantaged by freedom of mobility enabling accessibility to different meetings and trainings, and therefore, male-headed households have more access to information, thus influencing their agricultural practices [17].

It was noted that the respondents from the three counties varied in age with Kisii recording the highest number of young (18-35) farmers representing about $29.7 \%$ of the respondents (while the highest number of middle aged (36-45) farmers was again recorded in Kisii (36.3\%) and farmers aged up to 60 years, the highest number was recorded in Nyamira (52.8\%) (Table 1).

The age of household heads is an important variable which significantly influences farmers' information access [18]. Even though older farmers have the experience and the resources to explore new technology, however, these farmers do not utilize them. Studies have confirmed that age has a negative influence on the technology adoption by farmers. This is due to the fact that majority of farmers who utilize information and communication technology- (ICT-) based technology to access information on markets, new technology, and farming strategies are in the younger age groups and decrease as age increases as reported by Simon et al. [18]. Conversely, younger farmers are not only innovative and active participants in training activities but are also very quick in adopting newer technologies [17].

3.1.2. Level of Education and Occupation. It was established that majority of the respondents had attained at least primary school level of education. Fifty percent of the respondents from Nyamira, Kisii, and Embu had attained a secondary school education, while those with tertiary school education were $30 \%$ of the respondents in Kisii, Nyamira, and Embu counties (Table 1). Farmers with formal education are believed to have the ability to perceive, interpret, and respond to new information much faster than their counterparts without formal education. It has been reported that the level of education of farmers has a significant influence on awareness of trends in farming and also influences decision making $[5,19]$.

The current study established that farming is the main occupation of more than $50 \%$ of the respondents. Percentages of respondents in employment were 23\%, 20\%, and 9\% in Nyamira, Kisii, and Embu, respectively (Table 1). It was also observed that $30 \%$ of the respondents in Kisii engaged in business enterprises, while lower figures were reported in Embu (23.3\%) and Nyamira (16.7\%). An additional income source enables the farmer to have better investment capacity and gives the capacity to take more risks when experimenting with new technologies [19].

3.1.3. Source of Labour. Hired labour was the primary source of labour for farming activities in Nyamira, which was embraced by $50 \%$ of respondents. In Embu and Kisii, hired labour was reported by $46.7 \%$ and $36.7 \%$ of respondents, respectively. Most smallholder farms across the globe are characterized by utilization of family labour as the principal labour source [1]. Highest family labour utilization in farming was recorded in Kisii (40\%) with only $30 \%$ and $6.7 \%$ of respondents in Nyamira and Embu, respectively, reporting family labour use. Labour availability and access to reliable labour source and amount of labour available plays a significant role on farming practices. Availability of labour has been established to influence farm management practices as well as technology adoption by farmers [17].

3.1.4. Land Holding and Land Use in Kisii, Nyamira, and Embu Counties. The size of land available for farming varied among farmers in the three counties with $83.3 \%$ of the farmers in Kisii and $76.7 \%$ of the farmers in Nyamira had less than an acre of farm land. However, $26.7 \%$ of the farmers in Embu County had more than two acres of farm land (Figure 2). Different studies have shown contradicting effects of land size on agricultural practices and technology adoption therefore showing inconsistency. A study by Melesse [17] showed positive influence of the land holding capacity on agricultural practices and technology adoption.

Acreage allocated to cultivation varied between the counties. Majority of the farmers in Kisii (83.3\%), Nyamira (76.7\%), and Embu (36.7\%) cultivated farmland with acreage 0.4 to more than 0.5 acres of their land (Figure 2). Smallholder farmers in three counties practiced mixed farming systems in order to provide food for the homestead and the surplus for sale. Majority of the respondents in the three counties are practicing integrated farming which includes crop cultivation and livestock keeping and others such as poultry farming (Figure 3).

Among the respondents in Nyamira County, 76.7\% confirmed that they did not have title deeds of their respective farms which were closely followed by those at Kisii County (60\%). Embu County on the other hand had a higher number $(86.7 \%)$ of respondents who confirmed land ownership since they had title deeds (Table 1). Lack of proof of ownership of land exposes the farmers to a risk of land loss. According to Dawson et al. [20], reduced tenure security was a contributory factor to loss of land.

It was observed that respondents for Kisii, Nyamira, and Embu counties grew at least 20 crop varieties that included cereals, legumes, fruits, cash crops, and a variety of vegetables (Figure 4). Maize was the predominantly grown cereal in the three counties, while beans were the most popular legume, banana the most popular fruit, and sukuma wiki (kales) the most popular vegetable. Maize and bananas represented the most preferred type of crops. 
Table 1: Age distribution of respondents in Nyamira, Kisii, and Embu counties.

\begin{tabular}{|c|c|c|c|c|c|c|}
\hline \multirow{2}{*}{ Variable } & \multicolumn{2}{|c|}{ Nyamira } & \multicolumn{2}{|c|}{ Kisii } & \multicolumn{2}{|c|}{ Embu } \\
\hline & Frequency & Percentage & Frequency & Percentage & Frequency & Percentage \\
\hline \multicolumn{7}{|l|}{ Age group } \\
\hline 18-35 (youth) & 5 & 16.5 & 9 & 29.7 & 5 & 16.5 \\
\hline 36-45(middle age) & 7 & 23.1 & 11 & 36.3 & 7 & 23.1 \\
\hline $46-60$ & 16 & 52.8 & 8 & 26.4 & 15 & 50 \\
\hline $60+$ & 2 & 6.7 & 2 & 6.7 & 3 & 9.9 \\
\hline \multicolumn{7}{|l|}{ Gender } \\
\hline Male & 17 & 56.7 & 16 & 53.3 & 18 & 53.3 \\
\hline Female & 13 & 43.3 & 14 & 46.7 & 12 & 46.7 \\
\hline \multicolumn{7}{|l|}{ Education level } \\
\hline Primary & 5 & 16.7 & 6 & 20 & 5 & 16.7 \\
\hline Secondary & 16 & 53.3 & 15 & 50 & 16 & 53.3 \\
\hline Tertiary & 9 & 20 & 9 & 30 & 9 & 30 \\
\hline \multicolumn{7}{|l|}{ Occupation } \\
\hline Farming & 15 & 66.7 & 14 & 46.7 & 15 & 50 \\
\hline Employed & 7 & 33.3 & 7 & 23.3 & 9 & 30 \\
\hline Business & 6 & 20 & 9 & 30 & 6 & 20 \\
\hline \multicolumn{7}{|l|}{ Land ownership } \\
\hline Without title deed & 20 & 66.7 & 18 & 60 & 4 & 13.3 \\
\hline With title deed & 10 & 33.3 & 12 & 40 & 26 & 86.7 \\
\hline \multicolumn{7}{|l|}{ Labour source } \\
\hline Family & 9 & 30 & 12 & 40 & 2 & 6.6 \\
\hline Hired & 15 & 50 & 11 & 36.7 & 14 & 46.7 \\
\hline Hired + family & 6 & 20 & 7 & 23.3 & 14 & 46.7 \\
\hline
\end{tabular}

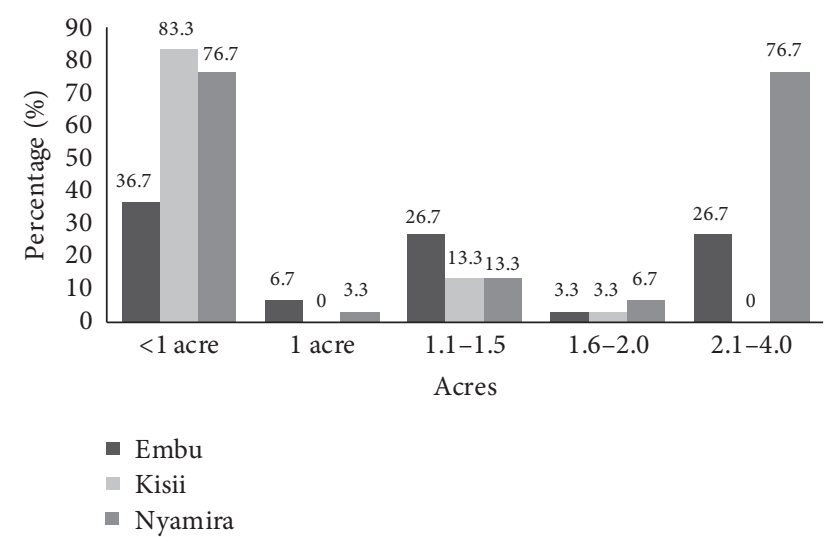

Figure 2: Land size of farmers in Kisii, Nyamira, and Embu counties.

3.2. Fruit Farming. Fruit farming is a major farming activity in Kisii, Nyamira, and Embu counties with banana being the highest ranking fruit out of the five fruit varieties (Table 2). This is followed by avocados in the three counties. However, banana is allocated more acreage in Embu County, and this is most likely due to larger farming land (Figure 1) with more than $60 \%$ of the respondents having more than an acre of farming land. Obaga and Mwaura [7] reported that in Kenya, the national average of banana plantations is 0.32 ha per farm.

It was observed that $86 \%$ and $93.3 \%$ of the respondents in Kisii and Nyamira counties, respectively, planted bananas on 0.2-0.5 acres. However, in Embu County, $40 \%$ of the

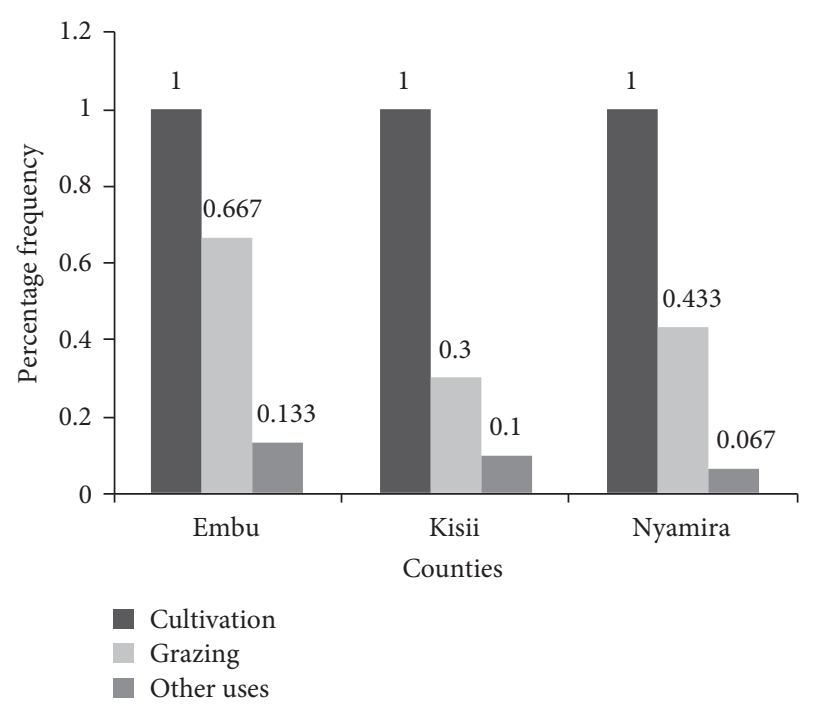

FIgUre 3: Mixed farming systems in Kisii, Nyamira, and Embu counties.

respondents grew bananas on 0.5 acres and above. It was observed that $93.3 \%, 80 \%$, and $80 \%$ of respondents in Kisii, Nyamira, and Embu counties, respectively, harvest more than 20 bunches annually averaging $22-35 \mathrm{~kg}$ per bunch. From the study, it was observed that Kisii was leading in banana production (Table 2). This agrees with a study by Obaga and Mwaura [7] which referred to Kisii as the leading producer of bananas in Kenya. The high banana production in Kisii County is attributed to banana being a staple food for 


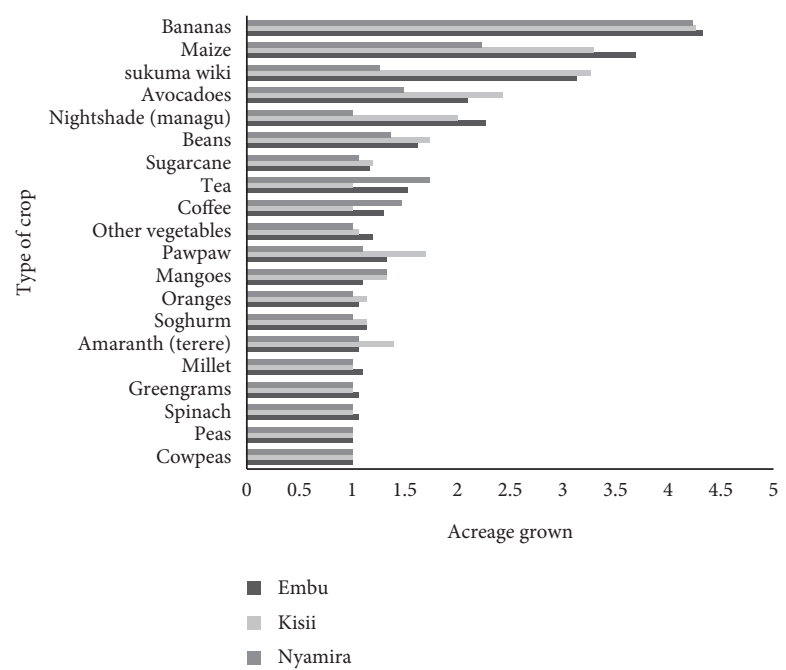

FIgURE 4: Crops grown by farmers in Embu, Kisii, and Nyamira counties.

Table 2: Yield index of fruits in Kisii, Nyamira, and Embu counties.

\begin{tabular}{lccr}
\hline & Kisii, mean \pm SE & Embu, mean \pm SE & Nyamira, mean \pm SE \\
\hline Banana & $5.80 \pm 0.14$ & $5.47 \pm 0.21$ & $4.23 \pm 0.21$ \\
Pawpaw & $1.40 \pm 0.09$ & $1.20 \pm 0.09$ & $1.10 \pm 0.07$ \\
Oranges & $1.10 \pm 0.06$ & $1.07 \pm 0.07$ & $1.00 \pm 0.00$ \\
Avocados & $2.07 \pm 0.16$ & $1.83 \pm 0.19$ & $1.50 \pm 0.18$ \\
Mangoes & $1.23 \pm 0.08$ & $1.10 \pm 0.07$ & $1.33 \pm 0.15$ \\
\hline
\end{tabular}

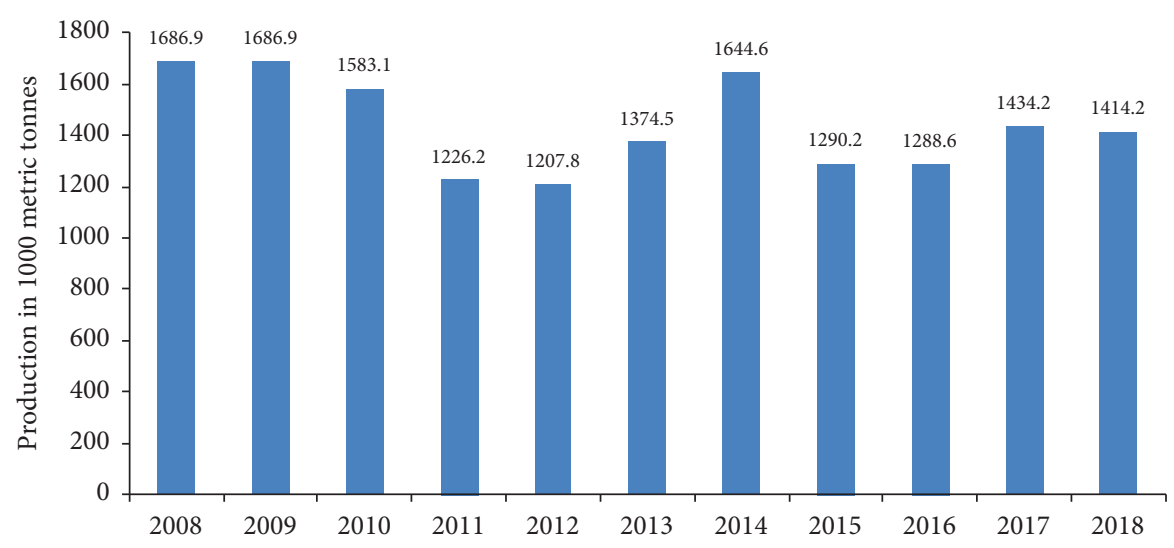

FIGURe 5: Production volume of bananas in Kenya 2008-2018.

the indigenous communities living in the region. Faria [21] reported that despite banana being an important fruit crop, production in Kenya has been on a decline over the years (Figure 5).

Embu County is among the leading banana producing Counties in Central Kenya. A 2019 CIDP report covering 2015-2017 of Embu County (Table 3) indicated that banana is the most produced crop; however, a decline in total production is a worrying trend [22].

In western Kenya, Kisii and Nyamira are among the leading producers of bananas (Figure 6). There is limited information of recent production trends; however, between 2010 and 2012, production in the two counties has shown decreasing trends in total production [23].

A survey of the preferred banana cultivars in the three counties showed that in Kisii and Nyamira, the most preferred cultivar was Ng'ombe with $73.3 \%$ and $90 \%$ of the respondents, respectively, planting the cultivar (Figures 7 and 8). However, in Embu County, the preferred cultivar was Israel with $96 \%$ of the respondents growing it followed by Moraru with $73 \%$ of the respondents growing the cultivar (Figure 9). 
TABLE 3: Embu crop production trend in 2015-2017.

\begin{tabular}{|c|c|c|c|c|c|c|}
\hline \multirow{2}{*}{ Horticultural crop } & \multicolumn{3}{|c|}{$2015 / 2016$ production } & \multicolumn{3}{|c|}{$2016 / 2017$ production } \\
\hline & In $\mathrm{Ha}$ & In tons & In Ksh “000” & In $\mathrm{Ha}$ & In tons & In Kshs “ 000 ” \\
\hline Mangoes & 3,185 & 112,640 & $1,689.6$ & 3,185 & 112,711 & 1,691 \\
\hline Bananas & 3,712 & 200,250 & $2,254.75$ & 3,593 & 162,450 & 5,581 \\
\hline Passion fruits & 30 & 500 & 29 & 25 & 300 & 37 \\
\hline Avocadoes & 529 & 8,808 & 145.68 & 529 & 10,200 & 428 \\
\hline Kales & 225 & 3,750 & 55 & 120 & 4,672 & 163 \\
\hline Tomatoes & 225 & 2,835 & 68.75 & 207 & 4,180 & 152.2 \\
\hline Carrots & 64 & 1,736 & 20.72 & 47 & 1,350 & 22.25 \\
\hline
\end{tabular}

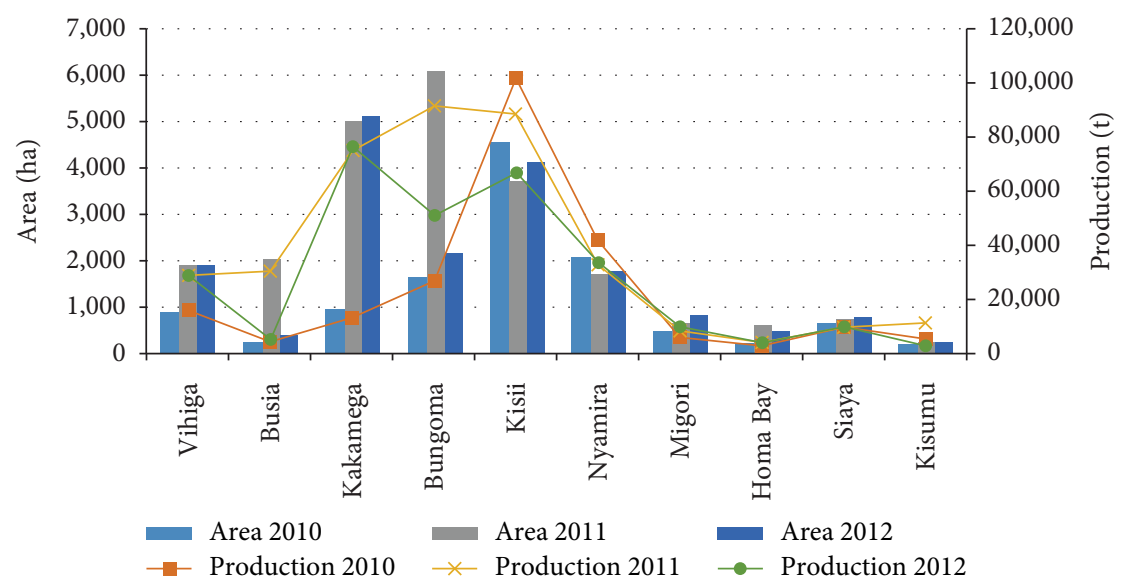

FIgURE 6: Banana area and production in western Kenya by county.

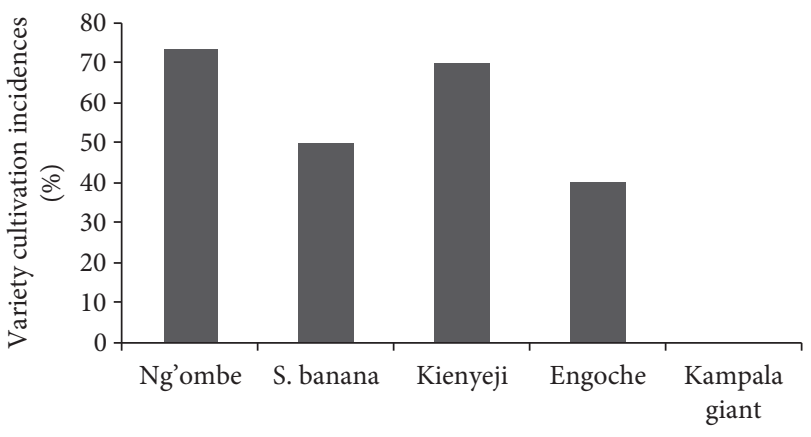

Banana varieties

Figure 7: Local banana varieties in Kisii County.

The respondent's preference of certain cultivars was based on the various characteristics that are outstanding. The $\mathrm{Ng}$ 'ombe variety which was the most cultivated cultivar in Kisii and Nyamira counties was preferred by the respondents due to their good taste and its ease to sale. Some respondents in Kisii and Nyamira counties also indicated that the cultivar produces big bananas. In Embu County, the Israel cultivar was the most preferred, and respondents indicated that its preference is due to its good taste and ease to sale similar to Ng'ombe in Kisii and Nyamira. Farmer's choice of cultivar is mostly determined by market demand and acceptability which is dictated by fruit characteristics [24].

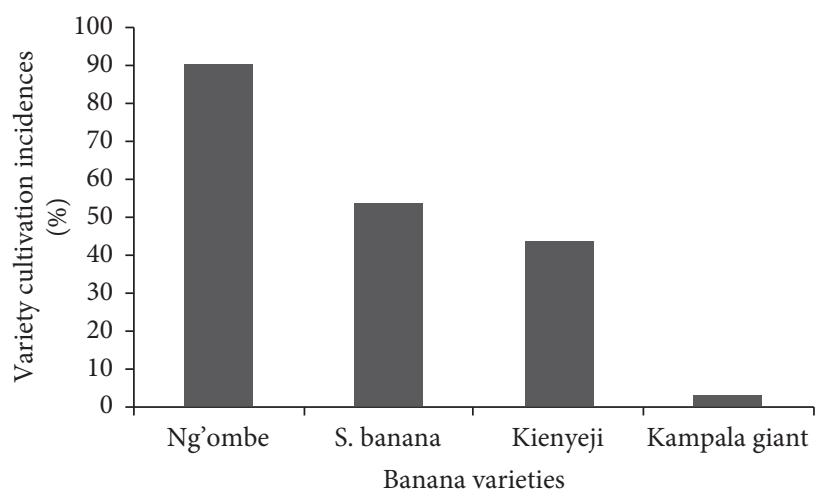

Figure 8: Local banana varieties in Nyamira County.

3.3. Factors Influencing Banana Farming in Kisii, Nyamira, and Embu Counties. Pests and diseases were ranked as the major challenge in banana production with Embu being the most affected with $73 \%$ of the respondents identifying pests and diseases as a major challenge (Figure 10). Lack of planting materials is ranked as the second significant challenge that is facing banana farmers, with Kisii County respondents being the most affected (Figure 11). Additional challenges were also identified, such as limited access to agrochemicals (pesticides, fungicides, and herbicides) which ranked third. A review by Ebiowe [9] established that pests and diseases are the principal challenges and yield limiting 


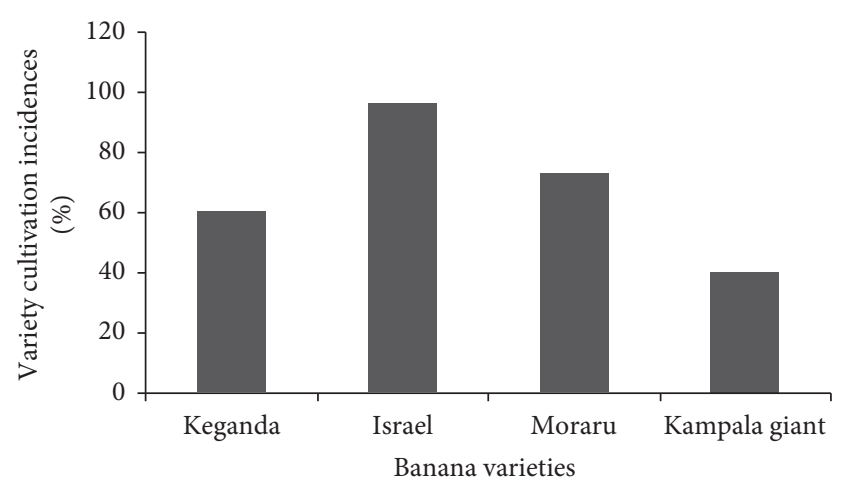

FIgURE 9: Local banana varieties in Embu County.

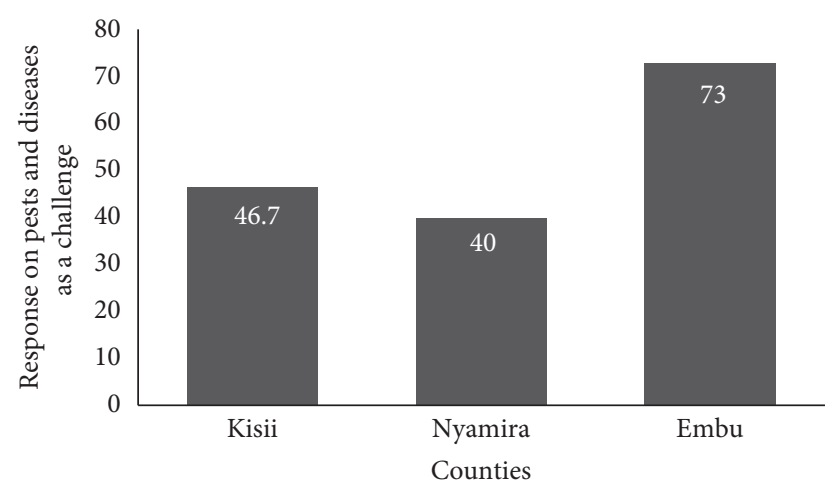

Figure 10: Pests and diseases as a challenge in banana farming.

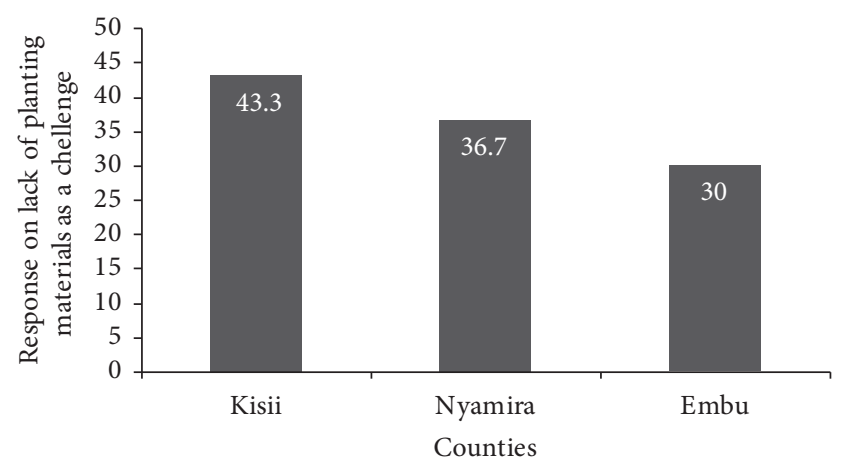

FIGURE 11: Lack of planting materials as a challenge in banana farming.

factors in banana-growing areas. Losses due to pests and diseases have increased over the years, and this is worsened by the high cost of chemicals and lack of improved banana varieties.

Conventional banana farming involves using suckers as planting materials. Due to limited planting materials, most farmers are forced to use suckers from existing orchards. The percentages of respondents obtaining suckers from their own farms in Nyamira, Embu, and Kisii were 73.3\%, 70\%, and $66.7 \%$, respectively. The rest of the respondents obtained the suckers from other commercial suppliers. The use of suckers from own farms may be a major contributing factor to pest

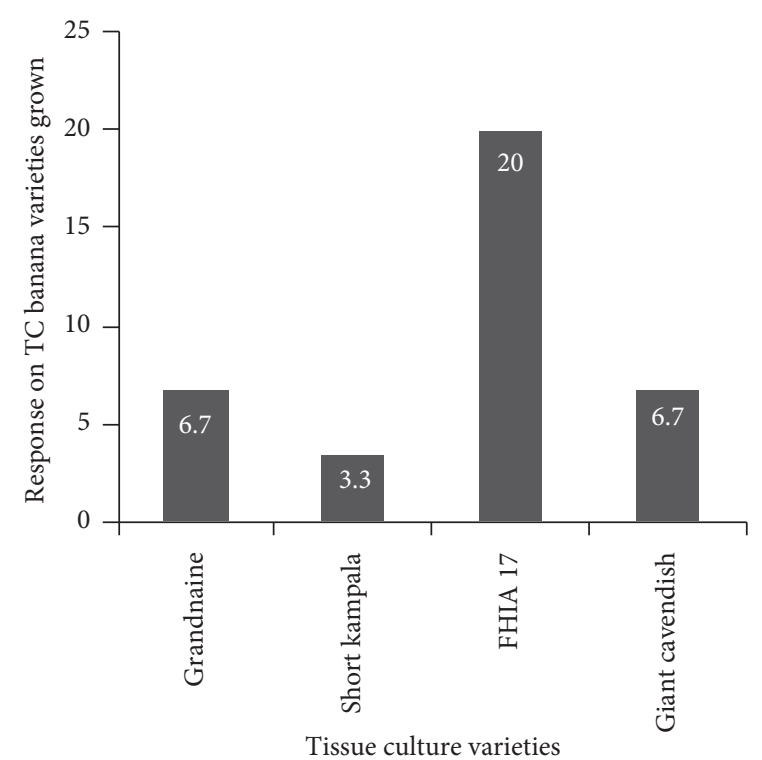

Figure 12: Tissue-cultured banana varieties grown in Embu County.

and disease prevalence as this may provide a means of disease spread through the use of infected planting material [1].

Majority of the respondents in Embu (70\%) and Nyamira (45\%) indicated that they sell their bananas to their neighbours, while $60 \%$ of the respondents in Kisii indicated that they sell to neighbours and at the local trading centres. Limited market access has majorly been attributed to inability to transport the produce due to poor transport infrastructure. Bananas have a disadvantage compared to other cash crops because there are no commodity boards or farmer organizations that aids farmers in accessing their requirements and accessing the markets [8]. As a result, farmers are left with limited market within their environs. In some instances, most farmers are always pushed into selling their bananas to unscrupulous brokers or intermediaries. This lowers the market price of the produce, since farmers have low bargaining power [8]. Market accessibility by farmers is important in technology adoption through input acquisition and product sales. Distance from the market raises transaction costs and markedly decimates farmers' profit margins [25].

The study identified that no value addition process was carried out by the respondents in the three counties. This concurred with a study by Muthee et al. [26], which indicated that farmers in Embu County sold their bananas unprocessed. Value addition has a great potential in increasing revenue obtained from bananas. A study by Obaga and Mwaura [7] indicated that a $40-50 \mathrm{~kg}$ bunch of banana retails at an average of 300 shillings in Kisii County, but after processing it into crisps, the same bunch fetches up to 1,680 shillings.

3.3.1. Banana Tissue Culture Technology Adoption. Knowledge of banana tissue culture technology was predominantly limited in which $60 \%$ of the respondents in Kisii, 


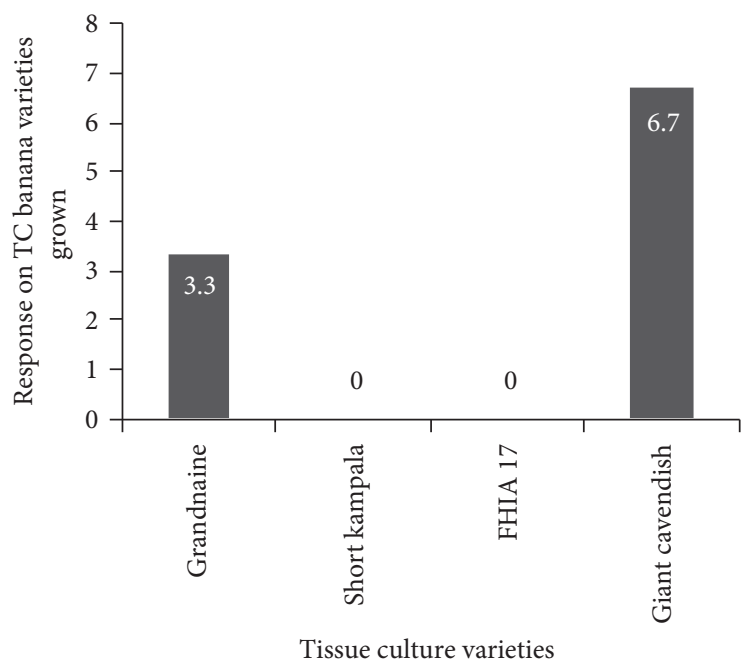

Figure 13: Tissue-cultured banana varieties grown in Kisii County.

66.7\% in Nyamira, and 63\% in Embu counties indicated that they did not know tissue-cultured (TC) bananas. Less than $35 \%$ of the respondents from the three counties indicated scanty knowledge on tissue culture technology. Embu County had the highest number of respondents (20\%) (Figure 12) planting tissue-cultured banana cultivars, followed by Kisii County (6.7\%) (Figure 13). However, only one respondent (3.3\%) in Nyamira County had planted tissue-cultured bananas (Figure 14). Twenty percent of the respondents who grew tissue-cultured bananas in Embu preferred FHIA 17 followed by grandnaine (6.7\%) and giant Cavendish (6.7\%) (Figure 12). Slow adoption rates of agricultural technologies continue to affect production with only less than $10 \%$ of all banana farmers in Kenya having adopted TC banana production so far $[1,27]$.

Tissue culture technology has the potential to improve productivity in banana farming; however, there are significantly low rates of tissue culture technology adoption among the respondents. Relevant stakeholders have noted that the technology adoption will go a long way in solving many agricultural, economic, social, and environmental problems [28]. It was noted that there is a general low adoption of tissue culture bananas technology despite the potential benefits of banana tissue culture techniques such as the production of many disease-free planting materials within a short duration [29].

The low TC adoption rate in Kisii and Nyamira can be explained by the fact that banana production in high potential areas is carried out under poor management. This is because production is relatively good even under poor management practices; therefore, the need for tissue-cultured banana varieties may not be felt [5].

Access to agricultural services such as contact with extension officers/agents was considered as a factor that contributed to low productivity in the three regions. It was established that none of the respondents in Nyamira and Kisii counties had contact with extension officers. Embu County differed from the Nyamira and Kisii counties, in which $23.3 \%$ of the respondents had access to services

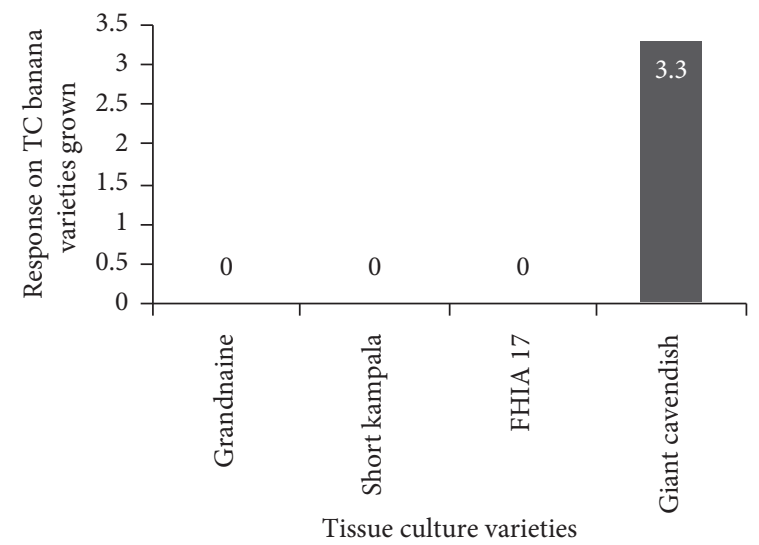

Figure 14: Tissue-cultured banana varieties grown in Nyamira County.

offered by extension officers. Pearson's correlation test revealed that there was a significant correlation at 0.01 level between access to agricultural services and whether or not the respondents had received farm management training. There was also a significant correlation between access to farm management training and knowledge on tissue-cultured banana technology (Table 4).

Lack of certified tissue-cultured banana seedling sources may be a major contributor to the low adoption rate of tissue culture technology, with only $11.1 \%$ of the respondents from the three counties indicating that they have a certified source for the seedlings. The significant correlation at 0.01 level of access farm management training and accessing TC banana seedling suggests that training has a vital role in information disseminating. Contact with extension officers has been reported to have a positive effect on the adoption of agriculture technology by farmers, and this is based on innovation diffusion theory [25]. When farmers are exposed to the available information, it stimulates adoption of a technology [26]. 
TABLE 4: Pearson's correlation coefficient for tissue-cultured bananas farming parameters.

\begin{tabular}{|c|c|c|c|c|c|c|c|c|}
\hline & Gender & $\begin{array}{l}\text { Banana } \\
\text { acreage }\end{array}$ & $\begin{array}{l}\text { Extension } \\
\text { services }\end{array}$ & $\begin{array}{c}\text { Farm } \\
\text { management } \\
\text { training }\end{array}$ & $\begin{array}{c}\text { Knowledge of } \\
\text { TC }\end{array}$ & $\begin{array}{c}\text { TC } \\
\text { farming }\end{array}$ & $\begin{array}{l}\text { Duration of } \\
\text { TC farming }\end{array}$ & $\begin{array}{l}\text { Availability of } \\
\text { TC seedlings }\end{array}$ \\
\hline Gender & 1 & & & & & & & \\
\hline Bananas acreage & 0.101 & 1 & & & & & & \\
\hline $\begin{array}{l}\text { Agricultural } \\
\text { services }\end{array}$ & 0.274 & $0.438^{* *}$ & 1 & & & & & \\
\hline Training & 0.223 & $0.434^{*}$ & $0.479^{* *}$ & 1 & & & & \\
\hline T.C knowledge & 0.290 & $0.431^{*}$ & 0.313 & $0.602^{* *}$ & 1 & & & \\
\hline TC farming & $0.397^{*}$ & $0.449^{*}$ & $0.398^{*}$ & $0.515^{* *}$ & $0.824^{* *}$ & 1 & & \\
\hline $\begin{array}{l}\text { Duration of T.C } \\
\text { farming }\end{array}$ & 0.343 & $0.453^{*}$ & $0.399^{*}$ & $0.539^{* *}$ & $0.893^{* *}$ & $0.922^{* *}$ & 1 & \\
\hline $\begin{array}{l}\text { Availability of T.C } \\
\text { banana seedlings }\end{array}$ & 0.274 & $0.369^{*}$ & 0.255 & $0.479^{* *}$ & $0.740^{* *}$ & $0.725^{* *}$ & $0.835^{* *}$ & 1 \\
\hline
\end{tabular}

${ }^{*}$ Correlation is significant at 0.05 level (2-tailed). ${ }^{* *}$ Correlation is significant at 0.01 level (2-tailed).

Agricultural technology is an essential tool in helping farmers adapt to the changing climatic conditions [25]. Setting up systems for collecting, processing, and sharing agricultural information is a necessity to ensure an increase in agricultural production. In addition to an efficient system in carrying out this activity, it could be used as a platform to train farmers in good banana farming practices, latest technologies, and market access. A more supportive policy environment with more robust and better-regulated linkages to markets (local and international) is required to maximize benefits from investments [7]. There is, therefore, a need to identify information communication technology tools that can aid in the dissemination of relevant information to farmers such as mobile technology in accessing market linkages, current market prices, as well as credit facilities [25].

\section{Conclusion}

The study revealed that banana farming is a common practice of smallholder farmers in Kisii, Nyamira, and Embu counties. Findings from the present study indicated that banana productivity is affected by key factors which have the potential to significantly lower their productivity in the study areas. The major factors include a limited supply of input ranging from planting materials, agrochemicals, as well as limited knowledge associated with good banana farming management practices. There is potential in enhancing banana production in the three counties; unfortunately, the knowledge gap among the residents and inaccessibility to important inputs in the three study areas is a hindrance. Although tissue culture is essential in increasing agricultural productivity and achieving sustainability in banana production, its adoption rates are very low, thus calling for a need to its promotion [30].

\section{Data Availability}

The data used to support the findings of this study are available from the corresponding author upon request.

\section{Conflicts of Interest}

The authors declare that there are no conflicts of interest.

\section{Acknowledgments}

The authors acknowledge the National Research Fund (NRF) for funding the research.

\section{References}

[1] B. Langat, V. Ng'eno, P. Nyangweso et al., "Drivers of technology adoption in a asubsisitence economy: the case of tissue culture bananas in Western Kenya," in Proceedings of the 4th International Conference of the African Association of Agricultural Economists Hammamet, pp. 22-25, Hammamet, Tunisia, September 2013.

[2] F. Nguthi, M. Onyango, F. Muniu, J. Muthama, and M. Njuguna, "Biotechnology to benefit small scale banana producers in Kenya," Annual report KARI, KARI, Nairobi, Kenya, 1997.

[3] J. Spilsbury, J. Jagwe, K. Wanda, and J. Nkuba, "Evaluating the marketing opportunities for banana growing countries of ASARECA," Regional report, International Institute of Tropical Agriculture, Ibadan, Nigeria, 2003.

[4] MOA, "Horticultural division annual report," Ministry of Agriculture, Nairobi, Kenya, 2005.

[5] N. Kabuga, T. Dubios, and M. Qaim, "Yield effects of tissue culture bananas in Kenya: accounting for selection bias and the role of complimentary inputs," Journal of Agricultural Economics, vol. 63, pp. 444-464, 2012.

[6] H. Singh, S. Uma, J. Selvarajan, and L. karihalo, Micropropagation for Production of Quality Banana Planting Material in Asian Pacific, Asian Pacific Consortium on Agricultural Biotechnology, New Delhi, India, 2011.

[7] B. Obaga and F. Mwaura, "Impact of farmer participation in banana value addition in household welfare in Kisii Central Sub-County," International Academic Journal of Social Sciences and Education, vol. 2, no. 1, pp. 25-46, 2018.

[8] FAO, Understanding Smallholder Farmer Attitudes to Commercialization-The Case of Maize in Kenya, FAO, Rome, Italy, 2014, http://www.fao.org/publications.

[9] P. Ebiowe, "Empirical review of problems and prospects of banana (Musa sapientum) and plantain (Musa parradisiaca) production enterprises," Global Journal of Biology, Agriculture and Health Sciences, vol. 2, no. 4, pp. 181-186, 2016.

[10] K. Ogero, N. Gitonga, M. Mwangi, and O. Ombori, "Response of two sweetpotato varieties regenerated on low cost tissue culture media," African Crop Sciences Conference, vol. 10, pp. 411-415, 2011. 
[11] N. Gitonga, O. Ombori, M. Muriithi, and M. Ngugi, "Low technology tissue culture materials for initiation and multiplication of banana plants," Africa Crop Science Journal, vol. 18, no. 4, pp. 243-251, 2010.

[12] Hortfresh, "Banana farming in Kenya, rise to a cash crop," 2019, https://hortfreshjournal.com/banana-farm.

[13] M. Makone, A. Basweti, and C. Ngeywo, "Farmers' response to organic and inorganic fertilizer utilization on maize cropping systems in Kisii county, Kenya," International Journal of Plant \& Soil Science, vol. 6, no. 1, pp. 26-33, 2015.

[14] O. Kenyanya, J. M. Wachira, and H. Mbuvi, "Determination of potassium levels in intensive subsistence agricultural soils in Nyamira County, Kenya," International Journal of Agriculture and Forestry, vol. 3, no. 7, pp. 294-302, 2013.

[15] J. Nyaga, J. M. Jefwa, C. W. Muthuri, S. A. Okoth, V. N. Matiru, and P. Wachira, "Influence of soil fertility amendment practices on ex-situ utilization of native arbuscular mycorrhizal fungi and performance of maize and common bean in Kenyan highlands," Tropical and Subtropical Agroecosystems, vol. 17, no. 2, pp. 129-141, 2014.

[16] G. Snedecor and W. Cochran, Statistical Methods, Iowa State University Press, Iowa City, IA, USA, 8th edition, 1989.

[17] B. Melesse, "A review on factors affecting adoption of agricultural new technologies in Ethiopia," Journal of Agriculture and Food Research, vol. 9, p. 226, 2018.

[18] O. L. Simon, F. I. Mwombe, I. S. Mugivane, and H. N. John, "Evaluation of information and communication technology utilization by small holder banana farmers in Gatanga district, Kenya," The Journal of Agricultural Education and Extension, vol. 20, no. 2, pp. 247-261, 2014.

[19] T. Tefera, G. Elias, E. Diro and I. Koome, Drivers of Adoption of Agricultural Technologies and Practices in Ethiopia, A Study Report from 30 Woredas in Four Regions, Addis Ababa/Wanengen: I CASCAPE, 2016.

[20] N. Dawson, A. Martin, and T. Sikor, "Green revolution in subsaharan Africa: implications of imposed innovation for the wellbeing of rural smallholders," World Development, vol. 78, pp. 204-218, 2016.

[21] J. Faria, "Production volume of bananas in Kenya 2008-2018 report," 2020, https:/www.statista.com/statistics/1171192/ production-volume-of-bananas-in-kenya.

[22] CIDP, "Embu county intergrated development plan," https:// www.embu.go.ke/wp-content/uploads/2019/09/ APPROVED-CIDP-2018-2022.pdfCounty report, CIDP, Vacoas-Phoenix, Mauritius, 2019, https:/www.embu.go.ke/ wp-content/uploads/2019/09/APPROVED-CIDP-2018-2022. pdfCounty report.

[23] J. Auma, "A situational analysis of agricultural production and marketing, and natural resources management systems in West Kenya," 2015, https://www.researchgate.net/ publication/323582520_A_situational_analysis_of_ agricultural_production_and_marketing_and_natural_ resources_management_systems_in_West_Kenya.

[24] J. Mbaka, M. Mwangi, and M. N. Mwangi, "Banana farming as a business: the role of tissue cultured plant material in Kenya," Journal of Applied Biosciences, vol. 9, no. 1, pp. 354-361, 2008.

[25] J. Wanyama, G. Obare, G. Owuor, and l. Wasilwa, "Assessing the determinants of tissue culture banana adoption in Western Kenya," African Journal of Food, Agriculture, Nutrition and Development, vol. 16, no. 1, 2016.

[26] A. Muthee, B. Gichimu, and P. Nthakanio, "Analysis of banana production practices and constraints in Embu County, Kenya," Asian Journal of Agriculture and Rural Development, vol. 9, no. 1, pp. 123-132, 2019.
[27] M. Njuguna, F. Wambugu, S. Acharya, and M. Mackey, "Socio-economic impact of tissue culture banana(Musa spp.) in Kenya through the whole value chain approach," Nairobi: Acta Horticulture, vol. 879, pp. 21-22, 2010.

[28] A. Nyande, Institute of Biotechnology Research (IBR), from Message from the Director, JKUAT Newsletter: http://www. jkuat.ac.ke/institute/ibr/, 2012.

[29] H. Wasala, Assessing Adoption of Banana Macro-Propagation by Small-Scale Farmers in Kisii County, University of Nairobi, Nairobi, Kenya, 2014, https://agrieconomics.uonbi.ac.ke/ index.php?q=node/1929.

[30] M. Ogada, G. Mwambu, and D. Muchai, "Farm technology adoption in Kenya: a simultaneous estimation of inorganic fertilizer and improved maize variety adoption decisions," Agricultural and Food Economics, vol. 2, p. 12, 2014. 